\section{SOUND FINANCIAL GUIDANCE}

Many (if not most!) of the thousands of dental professionals expected to attend the BDTA Dental Showcase will be in need of some sort of solution to a monetary problem of the kind that exclusively affects dentists; fortunately, the money4dentists team at stand R03 will be able to offer help and advice.

Whether they are dental staff, practice owners or associates, dental health professionals face unique financial issues and problems that go beyond the experience even of the best general financial advisers. With over half a century of experience giving specialist support on fiscal matters to dentists, money4dentists can lend a hand with issues including pensions, savings and investments, mortgages, tax planning and more.

Whatever your situation, money4dentists can offer you bespoke independent financial advice. Paying a visit to their helpful team at the BDTA Showcase to find out more about their services could be the best financial decision you make all year.

Money4dentists will also be launching their sister business, accountants4dentists, at this year's Dental Showcase.

Reader response number 65

\title{
AESTHETICALLY PLEASING ERGONOMIC FLEXIBILITY
}

The Italian manufacturer of dental units and instruments, Castellini, will be one of the $300+$ companies present at the 2011 BDTA Dental Showcase. The event is the ideal chance for dental practitioners to discover how Castellini's innovative and stylish designs can help them become more productive, precise, sanitary and comfortable during both invasive and non-invasive procedures.

The Company's units combine pleasing aesthetics with ergonomic flexibility and advanced computer

\section{TOTAL PEACE OF MIND}

Takara Belmont's portfolio of Treatment Centres promise to cater to any dentist's requirements. The flexibility of their range will be demonstrated at this year's Dental Showcase, highlighting the very best technical, hygienic and ergonomic features, backed up by free extended warranties offering total peace of mind.

Takara Belmont Treatment Centres are designed to please everyone. Left handed practitioners might opt for the Clesta II (factory installation option) or Voyager II-L which is suitable for ambidextrous use. Surgeries tight on space will benefit from the small footprint of the Cleo II whilst those technology for the benefit of dentists and their assistants. Their flexible nature not only helps dental health professionals to avoid the extremely common problem of back pain, but also allows them to take up a minimum amount of space in the restricted surroundings of many UK dental surgeries.

Visit Castellini on stand T01 to discover how their array of excellent products could change your surgery for the better.

Reader response number 66

treating the elderly and children can appreciate the easy access facilitated by its 'knee break' chair. Various installations are also available within the range, including continental rod, cabinet or mobile cart options. For those looking to increase functionality, the choice of electric versions of the Clesta II and Cleo II are available.

An extended warranty comes with every purchase of Takara Belmont equipment. Five years is offered on chairs and lights, three on units and spittoons and two on X-rays. And if it's X-ray units that you're interested in, you'll be excited to hear that Takara Belmont will be launching a new one at the Show! Visit stand D10. Reader response number 68

\section{A VAST RANGE OF PRODUCTS}

Practitioners interested in premium quality, industry-leading products for the dental practice will find all this and more with Blackwell Supplies at the BDTA Dental Showcase 2011.

Visit Blackwell Supplies' stand to see their vast range of products, which offers exceptional value for money and includes: Hogies: a collection of comfortable and durable eyewear encompassing eyeguards, visors, sunguards and miniscope loupes; Dentomycin Periodontal Gel: an adjunctive therapy to encourage healing when treating moderate to severe adult periodontitis; Nusonics MED: a triple enzyme bacteriostatic cleaner for CQC-standard reusable instrument decontamination; and Ledermix Dental Paste and Cement: for effective and targeted pain relief during endodontic treatment.

All equipment and materials ensure optimum safety and reliability while supporting compliance with industry requirements, including HTM 01-05 and CQC.

Reader response number 67

\section{IDENTIFY SUSPICIOUS SYMPTOMS}

Dental education course provider Smile On will be present at the BDTA Dental Showcase on stand W08 hoping to spread its message of innovative lifelong learning.

The Smile On stand will be promoting its range of educational materials throughout the three days. The learning resources on the detection and referral of oral cancer cases will be a particular focus this year. Figures from the British Dental Health Foundation show that early diagnosis of oral cancer increases survival rates of the disease from $50 \%$ to $90 \%$; the ability to identify suspicious symptoms is a valuable attribute for all practice staff.

Dental professionals visiting the Smile On stand will be able to learn more about the crucial role that their vigilance can play in the struggle against this deadly disease, in addition to their wide variety of courses covering topics from bleaching to clinical photography.

Reader response number 69 